\title{
Analisis Rembesan pada Perencanaan Pembangunan Bendungan Logung, Kabupaten Kudus, Jawa Tengah
}

\author{
Heni Setyawati ${ }^{1 *}$, Najib Najib ${ }^{1}$, Ahmad Syauqi Hidayatillah ${ }^{1}$ \\ ${ }^{1}$ Departemen Teknik Geologi, Fakultas Teknik, Universitas Diponegoro, Semarang
}

\begin{abstract}
ABSTRAK
Bendungan termasuk kedalam heavy construction sehingga bendungan menyimpan potensi bahaya yang besar dan memiliki resiko kerusakan fisik serta kegagalan fungsi. Salah satu kerusakan fisik serta kegagalan fungsi pada bendungan adalah erosi akibat mengalirnya air melalui lubang-lubang pada pondasi (piping). Penelitian ini bertujuan untuk mengetahui debit air bendungan yang merembes melewati as bendungan pada keadaan muka air normal dan banjir, serta mengetahui nilai faktor keamanan bendungan dari bahaya piping. Metode yang digunakan dalam penelitian ini adalah metode observasi lapangan meliputi pemetaan geologi, pengukuran geolistrik dan pemboran inti, serta perhitungan Faktor Keamanan (FK). Sampel inti batuan diuji di laboratorium untuk mengetahui sifat fisik dan mekanika tanah terutama nilai specific gravity dan void ratio. Perhitungan FK menggunakan simulasi dengan input muka air normal dan muka air banjir. Berdasarkan hasil dari pemetaan geologi, permukaan lokasi penelitian disusun oleh batupasir tuffan, tuff, dan breksi. Pengukuran geolistrik dan pemboran inti menunjukkan bahwa bagian bawah permukaan dari lokasi penelitian tersusun oleh tuff yang mendominasi bagian atas dan batupasir tuffan mendominasi bagian bawah. Debit rembesan sebelum grouting pada keadaan muka air normal adalah sebesar 14,33 $\mathrm{m}^{3} /$ hari dan berubah menjadi 9,49 $\mathrm{m}^{3} /$ hari, debit rembesan sebelum grouting pada kondisi muka air banjir sebesar $15,32 \mathrm{~m}^{3} / \mathrm{hari}$ dan berubah menjadi $10,17 \mathrm{~m}^{3} /$ hari. Nilai faktor keamanan piping Bendungan Logung pada saat sebelum di grouting adalah 1,38 dan naik menjadi 4,77 setelah di grouting.
\end{abstract}

Kata kunci : Bendungan Logung; faktor keamanan piping; rembesan; simulasi model.

\section{ABSTRACT}

Dams is a heavy construction and have a high risk of physical damage and malfunction. One of the physical damage and failure of the function of the dam is erosion due to the flow of water through holes in the foundation. This research is aimed to estimate the dam water flow that seeps through the Logung Dam axis in normal and flood water conditions, the value of the dam safety factor (SF) of piping risk. The method used in this research is field observation methods including geological mapping, geoelectrical measurement, core drilling, and SF estimation. The laboratory tests of core sample is carried out to determine the physical and mechanical properties of the soil, especially the value of specific gravity and void ratio. The SF estimation is by conducting simulation based on water level and flood water conditions. The geological map shows the surface of the study area is composed of tuff, tuffaceous sandstone and breccia. The electric sounding and core drilling show that the subsurface of the study area is composed of dominating tuff on the upper part, while tuffaceous sandstone dominating the lower part. The seepage discharge before grouting in normal water level is 14,33 $\mathrm{m} 3$ / day and changes to 9,49 m3 / day, seepage discharge before grouting at the flood water level is 15,32 m3 / day and changes to 10,17 m3 / day. The safety factor of the Logung Dam from piping at the time before grouting was 1.38 and increased to 4.77 after grouting.

Keywords : Logung Dam; safety factors of piping; seepage; modeling simulation.

\section{PENDAHULUAN}

Bendungan adalah bangunan berupa urugan tanah, urugan batu, beton dan/atau pasangan batu yang dibangun selain untuk menahan dan menampung air, dapat pula dapat pula dibangun untuk menahan dan menampung limbah tambang (tailing) atau menampung lumpur sehingga membentuk waduk, seperti yang tercantum dalam Peraturan Pemerintah Republik Indonesia Nomor 37 Tahun 2010. 
Bendungan termasuk ke dalam heavy construction sehingga menyimpan potensi bahaya yang besar dan memiliki resiko kerusakan fisik serta kegagalan fungsi. Potensi permasalahan pembangunan bendungan dapat dibagi menjadi dua hal utama yaitu dampak dari konstruksi bendungan dan paska konstruksi atau masa pemanfaatan dari bendung. Salah satu kegagalan dan kerusakan pada bendungan adalah erosi akibat mengalirnya air melalui lubanglubang pada pondasi (piping). Apabila air dari waduk merembes melalui tubuh atau pondasi bendungan urugan yang terdiri atas material tanah yang dipadatkan, maka tekanan hidroliknya akan didistribusikan terhadap tegangan pori yang merupakan pengikat antar butiran material (Azdan dan Samekto, 2008).

Penelitian ini dilakukan dengan tujuan untuk mengetahui nilai Faktor Keamanan (FK) bendungan terhadap bahaya piping. Selain itu juga menentukan rekomendasi rekayasa teknik untuk menambah nilai FK pada Bendungan Logung.

\section{TINJAUAN PUSTAKA}

Bendungan tipe urugan dibangun dengan cara menimbunkan bahan-bahan seperti : batu, kerikil, pasir, dan tanah pada komposisi tertentu dengan fungsi sebagai pengangkat permukaan air yang terdapat di dalam waduk disebut (Sosrodarsono dan Takeda, 2002). Pada penelitian ini, bendungan yang akan di bangun adalah bendungan urugan zonal inti vertikal dengan memiliki dua filter.

\section{Tanah}

Tanah adalah material berupa agregat (butiran) mineral-mineral padat yang tidak tersementasi (terikat secara kimia) satu sama lain dan berasal dari bahan-bahan organik, lapuk, disertai dengan zat cair dan gas yang mengisi ruang-ruang kosong di antara partikel-partikel padat tersebut (Das, 1995). Perbedaan antara pasir/ kerikil dan lanau/ lempung dapat diketahui dari sifat-sifat material tersebut: lanau/lempung seringkali terbukti kohesif (saling mengikat), sedangkan yang berbutir (pasir, kerikil) adalah tidak kohesif (tidak saling mengikat).

\section{Permeabilitas}

Permeabilitas didefinisikan sebagai sifat bahan berongga yang memungkinkan air atau cairan lainnya untuk menembus atau merembes melalui hubungan antar pori. Bahan yang mempunyai pori-pori kontinu disebut dapat tembus (permeable) (Soedarmo dan Purnomo, 1993).

Permeabilitas dapat diketahui dengan melakukan beberapa pengujian, yaitu :

1. Uji permeabilitas dengan Packer test

2. Uji permeabilitas dengan Open End Test

3. Uji Permeabilitas di laboratorium (metode tinggi energi tetap (constant head) dan metode tinggi energi turun (falling head)).

\section{Rembesan}

Ketika tekanan rembesan ke atas, yang terjadi dalam tanah sama dengan $i_{c}$, maka tanah berada pada kondisi mengapung. Keadaan semacam ini juga dapat berakibat terangkutnya butir-butir tanah halus, sehingga terjadi pipa-pipa didalam tanah yang disebut Piping. Pipa-pipa yang membentuk rongga-rongga dapat mengakibatkan fondasi bangunan mengalami penurunan, hingga mengganggu stabilitas bangunan (Hardiyatmo, 2010).

Piping dapat terjadi di tanggul, pondasi, ataupun tanggul pada pondasi. Piping yang terjadi di tanggul bendungan disebabkan oleh tiga proses yaitu erosi belakang, suffusion (terbawanya butiran tanah yang diakibatkan oleh rembesan) dan kebocoran yang terkonsentrasi. Erosi belakang terbentuk dari proses dimana erosi diawali dari pintu keluar titik rembesan dan progresif. Hasil erosi belakang membentuk suatu bagian yang terus menerus atau biasa disebut dengan piping.

Semakin cepat muka air turun ke bawah maka FK lereng akan semakin berkurang. Hal ini menunjukkan kecepatan penarikan permukaan air adalah faktor utama yang mempengaruhi stabilitas lereng. Semakin besar kecepatan penarikan level air maka akan semakin mengurangi stabilitas lereng.

\section{Grouting}

Grouting merupakan salah satu metode yang dapat digunakan untuk perbaikan tanah. Grouting diterapkan dengan cara menyuntikkan semen ke dalam tanah di bawah tekanan untuk mengubah karakteristik atau perilaku tanah (Nicholson, 2015).

Material grouting yang digunakan untuk mengisi retakan, celah-celah, dan ruang kosong yang berada di bawah tanah, tidak mengacu pada jenis-jenis tertentu. Material grouting memiliki 
berbagai macam sifat, dari yang memiliki viskositas sangat rendah sampai campuran padat dan cair yang kental (Karol, 2003). Bahan-bahan yang biasanya dijadikan bahan untuk grouting, yaitu campuran semen dan air, campuran semen, abu batu dan air, lempung dan air, serta campuran pasir dan air, dan lain-lain.

Jenis material yang digunakan untuk proyek ditentukan berdasarkan beberapa variabel, termasuk persyaratan khusus proyek, jenis tanah, perkiraan perpindahan material serta diperlukan juga pengaturan waktu dan sebagainya. Material grouting dapat dibedakan menjadi 3 kategori, yaitu :

1. Particulate (cement) grouts, yaitu partikel padat yang tersuspensi dalam cairan.

2. Chemical grouts, yaitu bahan yang sepenuhnya dilarutkan dalam cairan.

3. Compaction grouts, umumnya untuk mengantikan tanah granular longgar, memperkuat tanah berbutir halus, diklasifikasikan sebagai particulate grouts meskipun tidak dalam bentuk cairan. Semen yang diinjeksikan akan mengisi celah-celah rembesan atau bocoran yang terdapat di bawah permukaan, sehingga kecepatan air mengalami penurunan yang cukup signifikan.

Berkurangnya penurunan kecepatan air di bawah tanah menjadi alasan erosi tidak lagi dipertahankan. Grouting mempengaruhi kecepatan air di bawah permukaan karena melindungi celah-celah rembesan sehingga air tidak dapat lolos (Kalkani, 1997).

\section{METODOLOGI}

Data lapangan diambil pada saat pemetaan geologi, pengukuran geolistrik, dan pengeboran inti. Dari pemetaan geologi bisa didapatkan gambaran bagaimana persebaran litologi dipermukaan dari lokasi penelitian tersebut.

\section{Pengukuran Geolistrik}

Pengukuran geolistrik dilakukan pada sepuluh titik. Masing-masing titik memiliki bentangan yang berbeda tergantung dengan kondisi dari lokasi pengamatan. Keseluruhan titik pengamatan berada pada daerah dekat as bendungan. Hasil pengukuran geolistrik berupa log geolistrik yang dikorelasikan antar titik pengukuran untuk memperoleh gambaran penampang geolistrik.

\section{Pemboran Inti}

Pengeboran inti dilakukan pada delapan lokasi. Lima titik pengeboran pada bagian yang akan dibangun as bendungan, sedangkan tiga titik lainnya berada pada bagian hilir dari bendungan.

Hasil pengeboran inti disajikan dalam bentuk log bor dan dikorelasikan antar log bor untuk mendapatkan gambaran lapisan tanah atau batuan bawah permukaan. Pada saat pengeboran inti berlangsung, dilakukan juga uji permabilitas dengan menggunakan uji lugeon yang menghasilkan data permeabilitas dari masingmasing lubang bor.

Sampel hasil pengeboran dianalisis di laboratorium untuk mendapatkan data yang dibutuhkan, yaitu specific gravity dan void ratio. Selanjutnya dilakukan permodelan menggunakan software slide v.6.0 untuk menghitung perkiraan debit rembesan yang mungkin terjadi pada Bendungan Logung serta nilai faktor keamanan bendungan dari bahaya piping.

\section{Analisis Rembesan}

Analisa rembesan dilakukan menggunakan program Slide 6.0 dengan dua kondisi yaitu muka air waduk kondisi normal (elevasi +90,454 m) dan kondisi banjir (elevasi $+93,541 \mathrm{~m}$ ). Analisis dilakukan dengan memasukkan nilai permeabilitas dari material penuyusun bendungan berupa lempung, pasir dana tanah random.

\section{Analisis Faktor Keamanan Piping}

Rembesan merupakan salah satu permasalahan yang terjadi pada tubuh bendungan. Aliran rembesan yang terjadi pada tubuh bendungan dapat menyebabkan ikut terangkutnya butiranbuiran halus material penyusun bendungan. Jika proses pengangkutan meterial halus tersebut berlangsung secara terus menerus, maka akan menyebabkan terjadinya erosi pada pondasi bendungan (piping). Oleh karena itu, perlu dilakukan perhitungan faktor keamanan untuk mengetahui apakah suatu bendungan aman dari bahaya piping atau tidak. Faktor keamanan dari piping dapat dihitung dengan persamaan berikut:

$$
\mathrm{FK}_{\text {piping }}=\frac{l c}{l e}
$$

\section{Keterangan:}

$\mathrm{FK}_{\text {piping }}$ minimum $=4$, aman $($ Badan

Standarisasi Nasional, 2016).

$I e=$ gradien hidrolik debit

$I c=$ gradien hidrolik dari material 
Penentuan harga Ic menggunakan persamaan sebagai berikut:

$$
\begin{aligned}
I c & =\frac{S G-1}{1+e} \\
\mathrm{SG} & =\text { spesifik gravity } \\
\mathrm{e} & =\text { void ratio/ angka porositas }
\end{aligned}
$$

\section{Rekomendasi Penanggulangan Rembesan}

Metode grouting sebagai salah satu metode penanggulangan rembesan dapat ditentukan kedalamannya dengan menggunakan persamaan:

$$
\mathrm{D}=1 / 3 \mathrm{H}+\mathrm{C}
$$

dimana,

$\mathrm{D}=$ kedalaman lobang bor $(\mathrm{m})$

$\mathrm{H}=$ ketinggian air Pseudostatis waduk (m)

$\mathrm{C}=$ konstanta $(8-20)$

\section{HASIL}

\section{Litologi Hasil Pemetaan}

Terdapat beberapa jenis batuan didaerah penelitian ini dengan kondisi yang berbeda. Berdasarkan kondisi lapangan yang ditemukan, batuan didaerah ini terbagi menjadi 3 satuan batuan yaitu satuan breksi vulkanik, satuan batupasir tufan dan satuan tuf.

a. Satuan batuan tuff perselingan batupasir tufan. Satuan batuan ini terdiri dari perlapisan tufa yang berselingan dengan lapisan batupasir tufan. Secara keseluruhan, tufa pada satuan ini berwarna abu-abu terang hingga sedikit kecoklatan. Keadaaan batuan ini padat dan sedikit lapuk. Dibeberapa bagian terlihat hanya ada tufa sebagai material penyusun batuan, dibagian yang lain terlihat adanya material berupa litik yang tersentasi baik.

Warna dari batupasir tufan yang ditemukan adalah putih kekuningan. Ukuran butir pada perlapisan batupasir tufan ini bervariasi. Dibeberapa lapisan terlihat ukuran butir berkisar pada pasir sangat halus $(0,25-0,125$ $\mathrm{mm})$ hingga pasir sedang (0,5-0,25 $\mathrm{mm})$, dibeberapa lapisan lainnya terlihat ukuran butir dari pasir halus $(0,25-0,125 \mathrm{~mm})$ hingga kerikil (4-8 mm).

b. Satuan breksi vulkanik.

Satuan batuan ini terdiri dari batu breksi vulkanik hasil lelehan gunung muria purba. Satuan batuan ini terdapat pada bagian utara dari bakal genangan waduk. Singkapan dari batuan ini dapat ditemukan di pinggir aliran sungai. Breksi ini memiliki warna hitam keabuan saat basah dan abu-abu saat kering. Dibeberapa bagian singkapan, terlihat jika fragmen dari breksi ini berukuran tak seragam yaitu dari ukuran pasir kasar (1-2mm) hingga berukuran bongkah $(25-64 \mathrm{~mm})$. sementara dibagian lainnya terlihat fragmen yang cukup seragam dengan kisaran ukuran butir kerikilberangkal. Fragmen tersebut berupa pecahan batu andesit dengan bentuk meruncing hingga membundar.

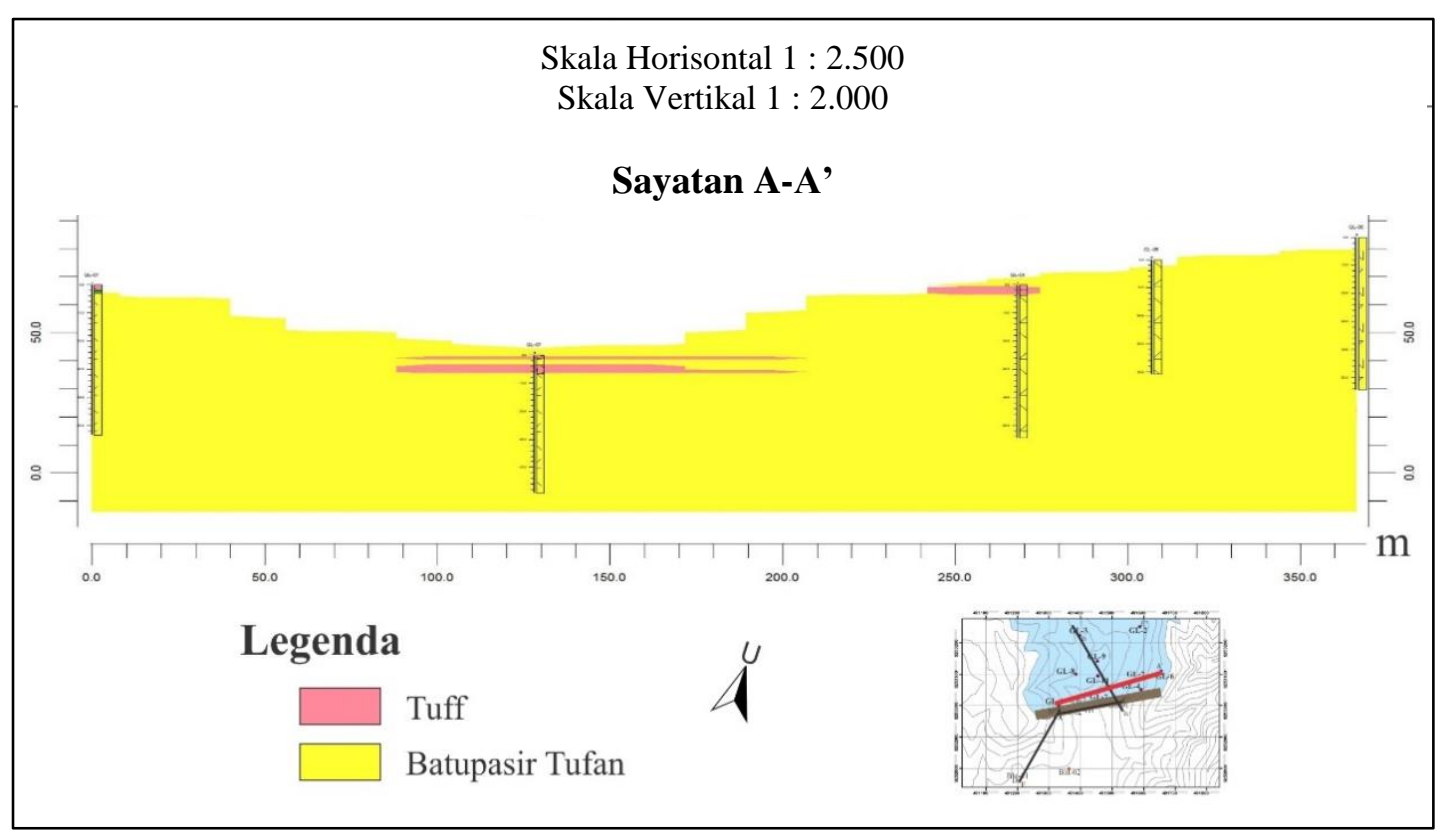

Gambar 1. Penampang korelasi log geolistrik Bendungan Logung, Kabupaten Kudus, Jawa Tengah. 


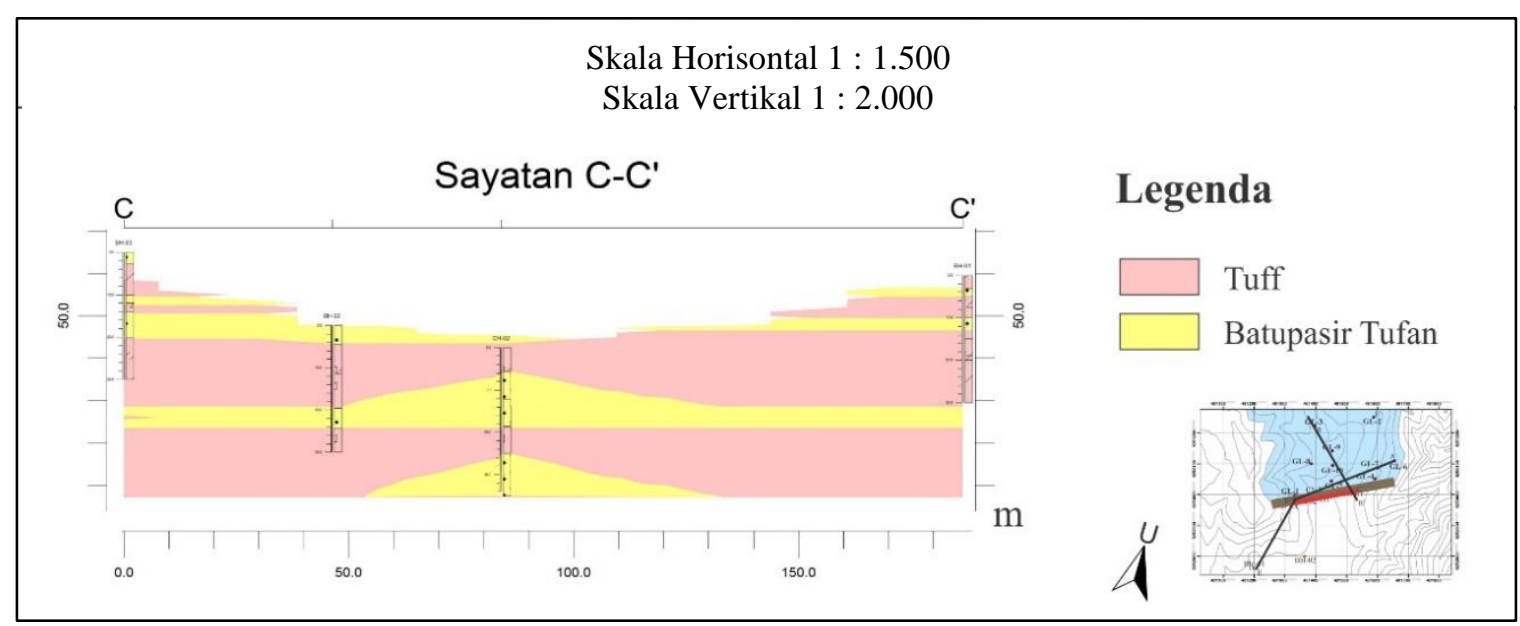

Gambar 2. Penampang korelasi titik pengeboran inti Bendungan Logung, Kabupaten Kudus, Jawa Tengah.

\section{Geolistrik}

Hasil pengolahan data geolistrik menunjukkan kesamaan litologi yaitu tuff pada daerah yang dekat permukaan dan batupasir tuffan yang mendominasi di bagian bawah lapisan batuan. Akan tetapi, terdapat beberapa lokasi geolistrik yang menunjukkan adanya lapisan batupasir tuffan di permukaan atau tuff yang ada pada pertengahan lapisan. Penampang korelasi log geolistrik dapat dilihat pada Gambar 1.

\section{Pengeboran Inti}

Log pemboran menunjukkan kondisi bawah permukaan pada lokasi pembangunan as menunjukkan adanya perlapisan antara batupasir tuffan dengan tuff. Batupasir tuffan mendominasi pada bagian atas hingga tengah core dan tuff dapat ditemukan menyebar dari atas hingga bawah core. Penampang korelasi log pengeboran inti disajikan pada Gambar 2.

\section{Analisis Debit Rembesan}

Hasil analisis pada Gambar 3 menunjukkan bahwa pada kondisi muka air normal, debit rembesan adalah $14,33 \mathrm{~m}^{3} /$ hari atau $1,66 \times 10^{-4}$ $\mathrm{m}^{3} / \mathrm{dtk}$ dengan nilai gradien hidrolik 0,6 . Gambar 4 menunjukkan hasil analisis pada kondisi muka air banjir, debit rembesan adalah $15,32 \mathrm{~m}^{3} /$ hari atau $1,77 \times 10^{-4} \mathrm{~m}^{3} / \mathrm{dtk}$ dengan nilai gradien hidrolik berkisar 0,6.

Rata-rata debit rembesan pada Bendungan Logung yaitu :

$\begin{array}{ll}\text { Q Muka Air Normal } & =1,66 \times 10^{-4} \mathrm{~m}^{3} / \mathrm{dtk} \\ \text { Q Muka Air Banjir } & =1,77 \times 10^{-4} \mathrm{~m}^{3} / \mathrm{dtk} \\ \Delta \mathrm{Q} & =1,715 \times 10^{-4} \mathrm{~m}^{3} / \mathrm{dtk}\end{array}$

Besarnya angka kebocoran yang melewati pondasi dan tubuh bendungan tidak boleh lebih dari $1 \%$ rata - rata debit sungai yang masuk ke waduk. (Departemen Pekerjaan Umum, 2005). Debit $(\mathrm{Q})$ sungai rata-rata pada daerah penelitian adalah $1,33 \mathrm{~m}^{3} / \mathrm{dt}$ dan $1 \%$ dari $\mathrm{Q}$ rata-rata sungai tersebut adalah $0,013 \mathrm{~m}^{3} / \mathrm{dtk}$, sehingga rata-rata kapasitas rembesan menjadi $0,00085808 \mathrm{~m}^{3} / \mathrm{dtk}$. Rata-rata kapasitas rembesan $<1 \%$ dari $\mathrm{Q}$ ratarata sungai $\left(0,013 \mathrm{~m}^{3} / \mathrm{dt}\right)$. Dengan demikian, kapasitas rembesan yang terjadi pada pondasi dan tubuh Bendungan Logung masih memenuhi dari syarat yang ditetapkan.

Nilai faktor keamanan dari piping pada tubuh Bendungan Logung hasil perhitungan menggunakan persamaan 2 dan 1 berturut-turut adalah:

$$
\begin{aligned}
\text { Ic } & =\frac{2,689-1}{1+1,0289}=0,832 \mathrm{~cm} / \mathrm{det} \\
\mathrm{FK}_{\text {piping }} & =\frac{0,832}{0,6} \\
& =1,38 \\
\mathrm{FK}_{\text {piping }} & <4 \text { (tidak aman) }
\end{aligned}
$$

Berdasarkan hasil perhitungan diketahui bahwa FK piping tubuh Bendungan Logung secara keseluruhan kurang dari FK minimum. Hal tersebut menunjukkan bahwa tubuh bendungan tidak aman dari bahaya piping.

\section{Penanggulangan Rembesan pada Tubuh Bendungan}

Tindakan penanggulangan rembesan pada Bendungan Logung tetap harus dilakukan, karena walaupun nilai kapasitas rembesan masih memenuhi syarat aman, tetapi FK piping tidak 


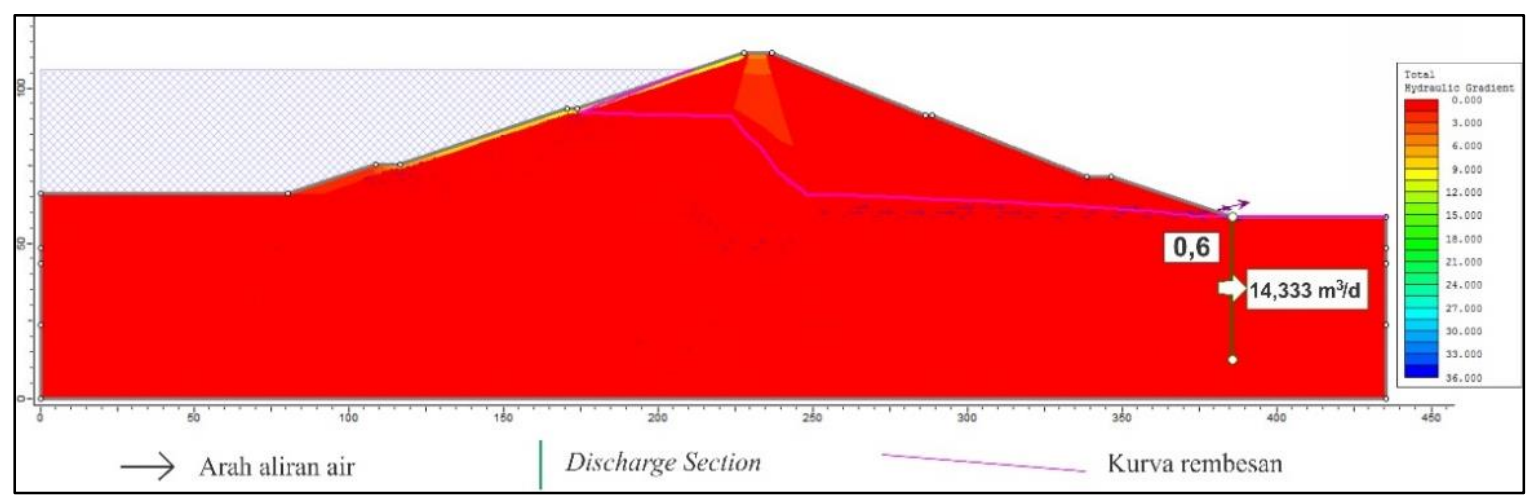

Gambar 3. Pemodelan rembesan pada kondisi muka air normal.

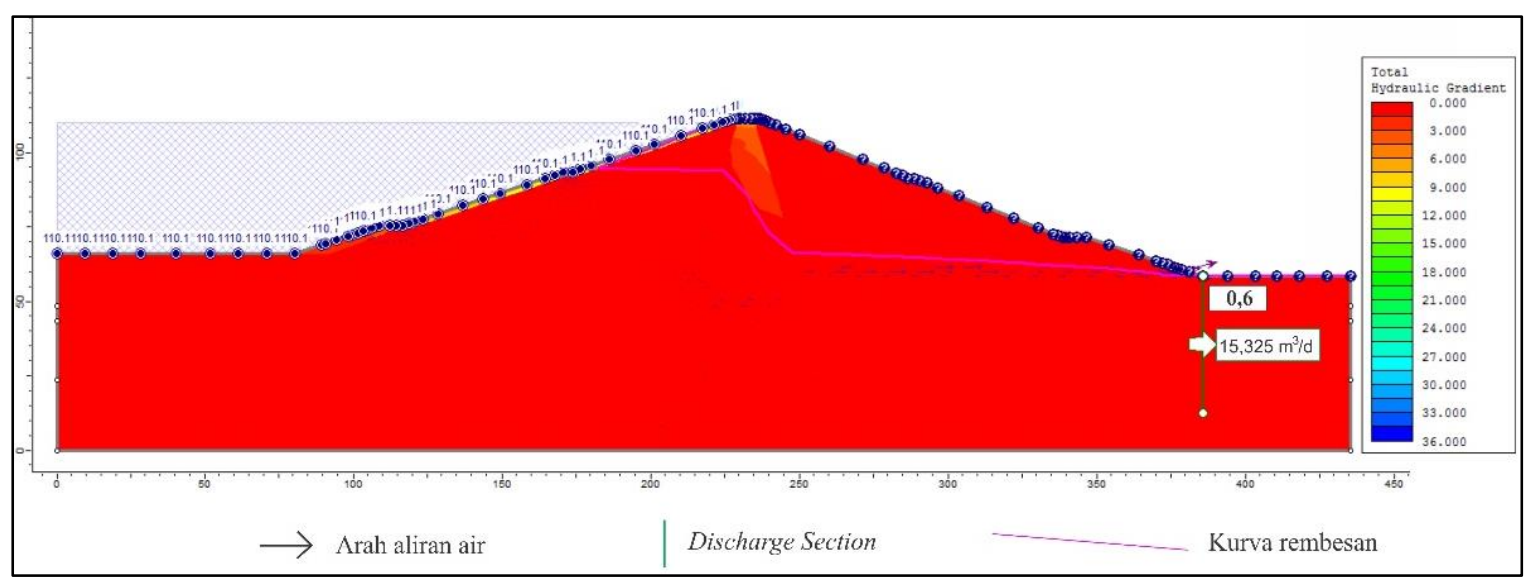

Gambar 4. Pemodelan rembesan pada kondisi muka air banjir.

mencapai standar yang telah ditentukan. Metode yang direkomendasikan untuk mengatasi permasalahan rembesan tersebut adalah grouting.

Ketinggian pseudostatis air waduk adalah 46 m dan konstanta yang dipakai dalam persamaan 3 adalah 8 dan 20. Hasil perhitungan dari persamaan 3 menyebutkan bahwa kedalaman lubang bor untuk melakukan grouting mencapai $30 \mathrm{~m}$ dari dasar bangunan bendungan.

Analisa debit rembesan dan $\mathrm{FK}$ piping dilakukan lagi untuk melihat perubahan nilai setelah dilakukan grouting. Perubahan nilai debit rembesan pada Bendungan Logung adalah sebagai berikut:

a. Debit Rembesan dengan Kondisi Muka Air Normal pada Gambar 5 menunjukkan bahwa pada kondisi muka air normal debit rembesan adalah $9,4995 \mathrm{~m}^{3} /$ hari atau $1,099 \times 10^{-4} \mathrm{~m}^{3} / \mathrm{dtk}$ dengan nilai gradien hidrolik berkisar 0,20.

b. Debit Rembesan dengan Kondisi Muka Air Banjir pada Gambar 6 menunjukkan bahwa pada kondisi muka air banjir debit rembesan adalah $10,171 \mathrm{~m}^{3} /$ hari atau $1,177 \times 10^{-4} \mathrm{~m}^{3} / \mathrm{dtk}$ dengan nilai gradien hidrolik berkisar 0,20.
Rata-rata debit rembesan pada Bendungan Logung yaitu :

Q Muka Air Normal $\quad=1,099 \times 10^{-4} \mathrm{~m}^{3} / \mathrm{dtk}$ Q Muka Air Banjir $\Delta \mathrm{Q}$

$$
=1,177 \times 10^{-4} \mathrm{~m}^{3} / \mathrm{dtk}
$$$$
=1,138 \times 10^{-4} \mathrm{~m}^{3} / \mathrm{dtk}
$$

Selanjutnya dilakukan kalkulasi faktor keamanan piping setelah grouting pada Bendungan Logung menggunakan persamaan 2 dan 1 dengan hasil sebagai berikut:

$$
\begin{aligned}
& \text { Ic }=\frac{2,69-1}{1+0,77}=0,954 \mathrm{~cm} / \mathrm{dtk} \\
& \begin{aligned}
\text { KK }_{\text {piping }}= & \frac{0,954}{0,20} \\
& =4,77
\end{aligned} \\
& \text { FK }_{\text {piping }}>4 \text { (aman) }
\end{aligned}
$$

Berdasarkan hasil perhitungan faktor keamanan piping di atas, diketahui bahwa faktor keamanan piping tubuh Bendungan Logung meningkat setelah grouting, perbandingan nilai tersebut disajikan pada Tabel 1. Peningkatan nilai faktor keamanan menunjukkan bahwa tubuh bendungan aman dari piping. 


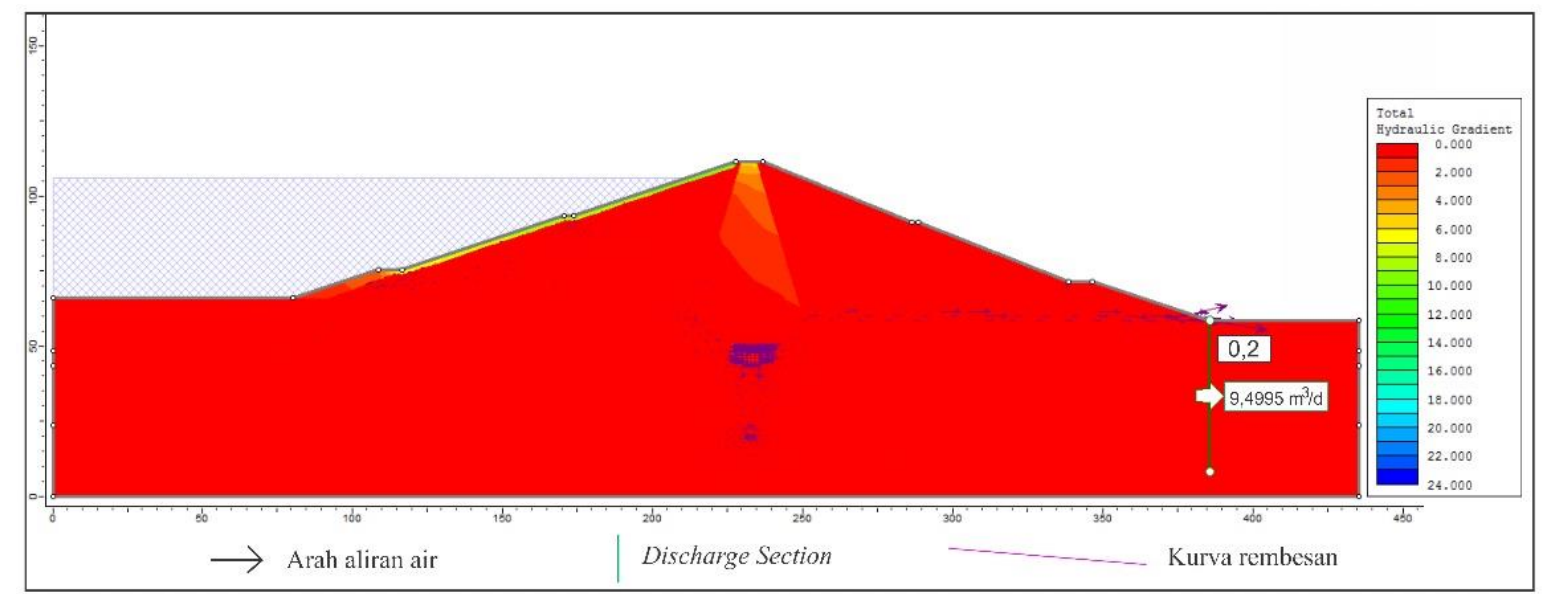

Gambar 5. Pemodelan rembesan pada kondisi muka air normal setelah grouting.

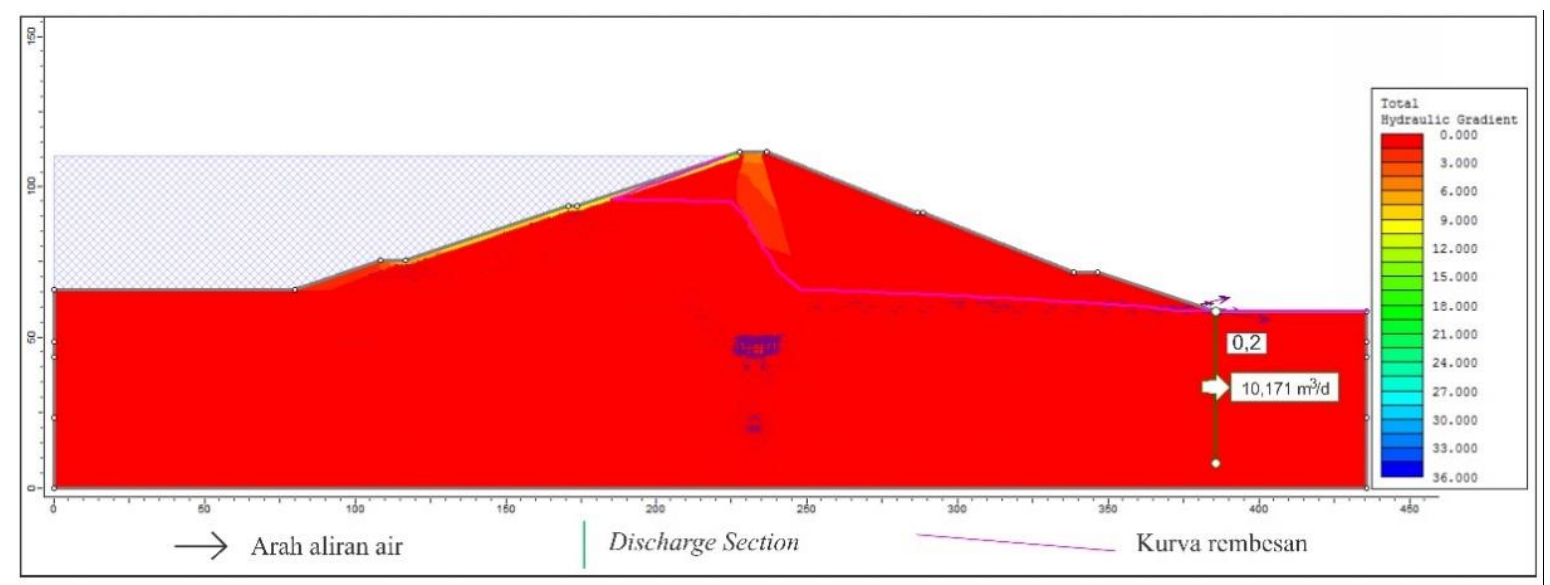

Gambar 6. Pemodelan rembesan pada kondisi muka air banjir setelah grouting.

Tabel 1. Perbandingan hasil analisis rembesan

\begin{tabular}{lcc}
\hline \multicolumn{1}{c}{ Parameter } & Sebelum Grouting & Sesudah Grouting \\
\hline Nilai SG (Specific gravity) & 2,689 & 2,69 \\
Nilai e (Void ratio) & 1,0289 & 0,77 \\
Debit rembesan pada muka air normal & $1,66 \times 10^{-4} \mathrm{~m}^{3} / \mathrm{dtk}$ & $1,099 \times 10^{-4} \mathrm{~m}^{3} / \mathrm{dtk}$ \\
Debit Rembesan pada muka air banjir & $1,77 \times 10^{-4} \mathrm{~m}^{3} / \mathrm{dtk}$ & $1,177 \times 10^{-4} \mathrm{~m}^{3} / \mathrm{dtk}$ \\
Gradien hidrolik debit & 0,6 & 0,2 \\
Gradien hidrolik dari material & 0,832 & 0,954 \\
FK & 1,38 & 4,77 \\
\hline
\end{tabular}

\section{KESIMPULAN}

Litologi bawah permukaan daerah penelitian tersusun atas batupasir tufan dan tuff. Debit rembesan, baik pada keadaan muka air normal maupun keadaan muka air saat banjir, mengalami penurunan $\left(+/-5 \mathrm{~m}^{3} /\right.$ hari atau $\left.+/-0,6 \times 10^{-4} \mathrm{~m}^{3} / \mathrm{dtk}\right)$ setelah dilakukan grouting. Nilai faktor keamanan piping Bendungan Logung sebelum grouting adalah 1,38 dan naik menjadi 4,77 setelah di grouting.

\section{SARAN}

Nilai faktor keamanan piping dari Bendungan Logung setelah di grouting memang mengalami 
kenaikan, tetapi faktor keamanan tersebut masih sangat dekat dengan nilai minimum faktor keamanan yang diijinkan, sebaiknya dilakukan peninjauan ulang untuk penentuan grouting, agar dapat lebih memperbesar nilai faktor keamanan.

\section{DAFTAR PUSTAKA}

Azdan, M. D. dan Samekto, C. 2008. Kritisnya Kondisi Bendungan di Indonesia. Seminar Nasional Bendungan Besar, Surabaya.

Badan Standarisasi Nasional. 2016 Metode Analisis dan Cara Pengendalian Rembesan Air untuk Bendungan Tipe Urugan, SNI 8065:2016. Jakarta.

Das, B. M., 1995. Mekanika Tanah : PrinsipPrinsip Rekayasa Geoteknik Jilid 1. Penerbit Erlangga: Jakarta.

Hardiyatmo, H. C., 2010. Mekanika Tanah 1 Edisi kelima. Universitas Gadjah Mada: Yogyakarta.

Kalkani, E. C., 1997. Geological conditions, seepage grouting, and evaluation of piezometer measurments in abutments of an earth dam. Engineering Geology, Vol 46, hal. 93-104.

Karol, R. H. 2003. Chemical Grouting and Soil Stabilization. Marcel Dekker, Inc.: New York, hal. 558.

Nicholson, P. 2015. Soil Improvement and Ground Modification Methods 1st Edition. Butterworth-Heinemann: United Kingdom.

Peraturan Pemerintah Republik Indonesia. 2010. Peraturan Pemerintah Tentang Bendungan No 37 BAB I, Pasal 1 Ayat 1.

Soedarmo, G. D. dan Purnomo, S. J. E., 1993. Mekanika Tanah 1. Kanisius: Malang.

Sosrodarsono, S. dan Takeda, K. 2002. Bendungan Tipe Urugan. PT. Pradnya Paramita: Jakarta. 